\title{
Development of nickel and silver ceramic filters supported on K10 montmorillonite clay for water disinfection
}

\section{(Desenvolvimento de filtros cerâmicos com níquel e prata suportados em argila montmorilonita K10 para desinfecção de água)}

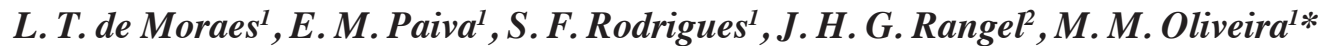 \\ ${ }^{1}$ Instituto Federal do Maranhão, PPGEM, Av. Getúlio Vargas 4, 65030-005, S. Luís, MA, Brazil \\ ${ }^{2}$ Instituto Federal do Maranhão, PPGQ, S. Luís, MA, Brazil
}

\begin{abstract}
This study aimed to obtain ceramic filters with bactericidal action for water disinfection. For this, aqueous suspensions of montmorillonite K10 clay were prepared at concentrations of $48 \%, 50 \%$, and $52 \%$. Later, these were impregnated into polymeric sponges in order to form the ceramic skeletons by using the replica technique. The ceramic filters were submerged in nickel resins doped with 0.25 and $0.50 \mathrm{~mol} \%$ silver. These resins were obtained by the Pechini method and heat-treated at 600 and $700{ }^{\circ} \mathrm{C}$ for $2 \mathrm{~h}$. Moreover, techniques such as X-ray diffraction, particle size analysis, scanning electron microscopy, energy dispersive spectroscopy, compressive strength, water absorption, and apparent porosity were used to characterize the filters, and their performance was analyzed by a bactericidal test. The bactericidal test results showed that the filters impregnated with the resin containing $0.50 \mathrm{~mol} \%$ of silver promoted the total elimination of the Staphylococcus aureus and Escherichia coli bacteria.
\end{abstract}

Keywords: Pechini method, nickel, silver, K10 montmorillonite clay, ceramic filter.

\section{Resumo}

Este trabalho visou a obtenção de filtros cerâmicos com ação bactericida para desinfecção de água. Para isto, suspensões aquosas de argila montmorilonita K10 foram preparadas nas concentrações de $48 \%$, 50\% e 52\% e impregnadas em esponjas poliméricas para formação dos esqueletos cerâmicos por meio do método de réplica. Os filtros cerâmicos foram submersos nas resinas de níquel dopadas com 0,25 e 0,50 \% mol de prata obtidas pelo método Pechini, e tratadas termicamente a 600 e $700^{\circ} \mathrm{C}$ por $2 \mathrm{~h}$. Os filtros foram caracterizados por difração de raios X, análise de tamanho de partícula, microscopia eletrônica de varredura, espectroscopia por energia dispersiva, resistência à compressão, absorção de água, porosidade aparente e teste bactericida. Os resultados do teste bactericida mostraram que os filtros impregnados com a resina contendo 0,50 \% mol de prata promoveu a eliminação total das bactérias Staphylococcus aureus e Escherichia coli.

Palavras-chave: método Pechini, níquel, prata, argila montmorilonita K10, filtro cerâmico.

\section{INTRODUCTION}

Worldwide, about 3 out of 10 people, a total of 2.1 billion, do not have access to safe drinking water at home, and 6 out of 10, or 4.5 billion, suffer from lack of safe sanitation. According to these data, 10 million people die annually from intestinal diseases transmitted by water, and studies show that more than 780 million people still do not have access to drinking water sources [1]. This problem is directly related to the quality of the water consumed by these people $[2,3]$. One of the solutions to mitigate the

*marcelo@ifma.edu.br

Dhttps://orcid.org/0000-0003-4991-8157 contamination of water for human consumption is the use of ceramic filters. This can drastically reduce the number of bacteria reaching close to $100 \%$ efficiency. Ceramic material is often used in water filters due to the ease formation of a uniform structure containing small pores. Such ceramic structures have the facility to remove many contaminants in the water, which is done through the size of the pores or by adhering to their walls [4-6]. In addition, ceramic filters can be shaped into different geometric shapes $[4,7]$. There are several techniques used for the manufacture of porous ceramics: replica method [8], gelcasting [9], incorporation of organic materials into the ceramic powder [10], generation of bubbles within the suspension [11], among others. The replica method used in this study is simple, low-cost, and 
widely used by the industry. This consists of impregnation of a polymeric sponge with a ceramic slip, followed by thermal treatment for the calcination of the organic material. Further, these filters are sintered, resulting in a ceramic body that is a replica of the precursor sponge used for the impregnation $[12,13]$.

Clays in the presence of water develop a series of properties such as plasticity, mechanical resistance, linear drying shrinkage, and compaction [14]. Among them, bentonite clays present approximately 140 industrial applications [15] and are abundant in Brazil [16]. Commercial montmorillonite $\mathrm{K} 10$ is obtained from natural montmorillonite in order to obtain a high surface area and acidity [17] and has been studied by several researchers. This material has a variety of applications in various industrial sectors like cosmetics, pharmaceuticals, support for chemical reactions, water clarification, etc. [18-21]. The technique of silver nanoparticles deposition in substrates such as montmorillonite, polymers, polymeric foams, ceramics, and activated carbon has also been studied [3, 22]. These particles are potentiators in the water filtration process by means of porous ceramics. Their effectiveness has been proven to reduce Escherichia coli and other bacterial indicators in drinking water [23-25]. Silver particles have a great affinity for compounds that have sulfur and phosphorus in their arrangement, and which are still present in the membrane structure as well as in the interior of bacteria. The interaction that occurs with the bacterial cell membrane compromises the process of cellular breath, and the one that occurs inside the bacteria interacts with DNA preventing cellular division [23].

In this research, a novelty regarding the production of low-cost ceramic filters using materials from cheap sources and which present excellent mechanical properties is presented. These are considered low-cost because of material and processing (polymeric sponge replica technique) cost in this investigation was approximately $\mathrm{R} \$ 7.00$ (USD 1.35) per produced filter. These filters were developed by using the replica method with nickel resins doped with silver and deposited in montmorillonite K10 ceramics having bactericidal action in order to disinfect water. Nickel element was used in resin synthesis due to its ease ability to form nanoparticles on the surface of the material with welldefined periodic arrangements [26]. These configurations contributed to the homogeneous distribution of the doped silver element into the porous filter structures. Thus, the obtained prototype constitutes an innovation for the quality of life to those who suffer from basic sanitation limited access. The final product presented success performance for the application in the process of water cleaning and disinfection.

\section{METHODOLOGY}

Manufacturing process of the ceramic filters: for the suspension preparation, different contents of solids were used in order to find the best composition for the synthesis of the ceramic filter. As a reference, a commercial composition of ceramic filter, with a $50 \%$ solids concentration, was used [27]. Compositions with $48 \%, 50 \%$, and $52 \%$ (mass fraction) of K10 montmorillonite clay (Aldrich, surface area: 250 $\mathrm{m}^{2} . \mathrm{g}^{-1}$ ) in water were used; for the suspensions, $0.864,1.5$, and $2.08 \mathrm{~g}$, respectively, of sodium polyacrylate (Darvan 7) was added as a deflocculant. The rheological analyzes were performed with a viscometer (Ultra DV3, Brookfield) in which the apparent viscosity was determined as a function of the shear rate for the suspensions used in this research. Deflocculation curves of the ceramic suspensions were obtained for the 3 described conditions. For the replica of the ceramic filters, polyurethane sponges (Condor) were used as a template. For the investigation of thermal degradation, thermogravimetric analysis (TGA) of the polymeric sponge was carried out in a thermobalance (TGA-50, Shimadzu) with a gas flow of $250 \mathrm{~mL} \cdot \mathrm{min}^{-1}$, from room temperature up to $1000{ }^{\circ} \mathrm{C}$, and a heating rate of $10{ }^{\circ} \mathrm{C} \cdot \mathrm{min}^{-1}$. The impregnation was performed by immersing the polymeric sponge in the ceramic suspension, followed by the passage of the impregnated sponges in a manual roller (opening between cylinders of approximately $20 \%$ of the thickness of the sample). The fraction of mass retained in the impregnated polymeric sponge of the ceramic suspension was calculated by the difference in mass between the impregnated samples before and after passing through the manual roller. Then, the impregnated sponges were submitted to the sintering process in an oven (Q318S, Quimis) at a heating rate of $10^{\circ} \mathrm{C} \cdot \mathrm{min}^{-1}$, from room temperature to $280^{\circ} \mathrm{C}$ for $26 \mathrm{~min}$ to eliminate the polymer, and then the temperature was raised to $1050{ }^{\circ} \mathrm{C}$ at a heating rate of $10^{\circ} \mathrm{C} \cdot \mathrm{min}^{-1}$ and a holding time of $77 \mathrm{~min}$.

Preparation of the resin: the synthesis methodology was based on Pechini's patent [28] and initially consisted of the preparation of the polymeric precursor solutions. For the nickel citrate preparation, $0.134 \mathrm{~mol}$ of nickel nitrate hexahydrate (Merck, 99\%) reacted with $0.401 \mathrm{~mol}$ of citric acid (Synth, 99.5\%) in a proportion of 1:3 for the formation of chelates. Subsequently, this mixture was heated to $80^{\circ} \mathrm{C}$ until the formation of a homogeneous system, under constant agitation, thus favoring the formation of the nickel complex. The same procedure was adopted to prepare silver citrate, and $0.068 \mathrm{~mol}$ of silver nitrate (Metalms, 63.5\%) reacted with $0.203 \mathrm{~mol}$ of citric acid. The citrates were mixed until complete homogenization and then heated to $60{ }^{\circ} \mathrm{C}$. Later, $1.5369 \mathrm{~g}$ of ethylene glycol (Synth, 99\%) was added in a ratio of $60 / 40(\mathrm{w} / \mathrm{w})$ of citric acid/ethylene glycol (CA/EG). The system was heated at $90{ }^{\circ} \mathrm{C}$ until acquiring a viscous consistency. The mixture of nickel and silver resins aimed to obtain the systems $99.75 \% \mathrm{NiO} / 0.25 \% \mathrm{Ag}$ and $99.50 \%$ $\mathrm{NiO} / 0.50 \% \mathrm{Ag}$. Afterward, the resin was subjected to a precalcination at $250{ }^{\circ} \mathrm{C}$. The product was ground with a mortar and pestle to decrease its size and increase its surface area. Then a second heat-treatment at $450{ }^{\circ} \mathrm{C}$ for $2 \mathrm{~h}$ was applied. After this, it was separated into two samples and placed in different crucibles for heat-treatment at 600 and $700{ }^{\circ} \mathrm{C}$ for 2 $h$. To impregnate the filters with the resin, the samples were cleaned with a fine brush and then placed in the precursor 
solution, containing nickel resin doped with silver, for 30 $\mathrm{min}$. Later, they were dried in the oven at $80^{\circ} \mathrm{C}$ for $30 \mathrm{~min}$. Subsequently, heat-treatment was carried out at 600 and $700{ }^{\circ} \mathrm{C}$, with a heating rate of $10{ }^{\circ} \mathrm{C} \cdot \mathrm{min}^{-1}$, with a holding time of $2 \mathrm{~h}$.

Characterization of nickel resin doped with silver: the techniques used for the characterization of nickel and silver resins were: X-ray diffraction (XRD) and particle size. Mineralogical analyzes were performed on a diffractometer (XRD-6100, Shimadzu) with $\theta / \theta$ geometry and $\mathrm{CuK} \alpha$ monochromatic radiation $(\lambda=1.540598 \AA)$. The particle size analysis of the obtained powders was performed in acoustic spectroscopy equipment (Zeta-APS, Matec). Characterization of ceramic filters: the morphology of the ceramic filters was analyzed in a scanning electron microscope (SEM, VEGA 3 LMU, Tescan) coupled with an energy-dispersive spectrometer (EDS, Aztec Energy $\mathrm{X}$-Act, Oxford, resolution $129 \mathrm{eV}$ ) for qualitative and semiquantitative microanalysis of chemical elements present in the sample. The physical properties, water absorption (WA), apparent porosity (AP), and bulk density (BD) were determined by the Archimedes method, according to NBR 13818 standard [29], and the compressive strength by the axial compression test on a $3000 \mathrm{kN}$ machine (DL, Emic). All tests were done in triplicate. Bactericidal efficiency analysis: samples of contaminated water were collected through ceramic filters impregnated with nickel oxide resin doped with silver in the compositions of 0.25 and 0.50 mol\%, treated at 600 and $700{ }^{\circ} \mathrm{C}$, and also a ceramic filter sample not impregnated with resin for comparison. For each collection, a sterile and properly identified container was used. Three samples of each filtration were collected. For the culture of bacteria, the technique of plating in-depth (pour plate) in a standard agar for counting (SAC, L A0066.08. AG, Synth) was used. For this procedure, $1 \mathrm{~mL}$ of each filtrate was pipetted into the sterile Petri dish, and $20 \mathrm{~mL}$ of SAC, previously melted and cooled to $45^{\circ} \mathrm{C}$, were added to each plate. After solidification, the inverted plates were incubated at $35^{\circ} \mathrm{C}$ for $48 \mathrm{~h}$.

\section{RESULTS AND DISCUSSION}

Thermogravimetric analysis (TGA) of polymeric sponge: TGA curve and its derivative DTG curve of the polymeric sponge are shown in Fig. 1. It was observed that the thermodecomposition process of the polyurethane sponge had 2 stages. The $1^{\text {st }}$ stage at $270{ }^{\circ} \mathrm{C}$ occurred slowly, with a more discrete decay in the curve, and the $2^{\text {nd }}$ at $300{ }^{\circ} \mathrm{C}$, when the reaction proceeded quickly. A series of secondary reactions occurred close to this $2^{\text {nd }}$ stage, which was in accordance with the literature [30].

Analysis of suspension deflocculation curves: the behavior of the aqueous suspensions with $48 \%, 50 \%$, and $52 \%$ of montmorillonite clay as a function of the sodium polyacrylate deflocculant concentration was investigated. This aimed to determine the amount of deflocculant that could be used in each suspension formulation based on the

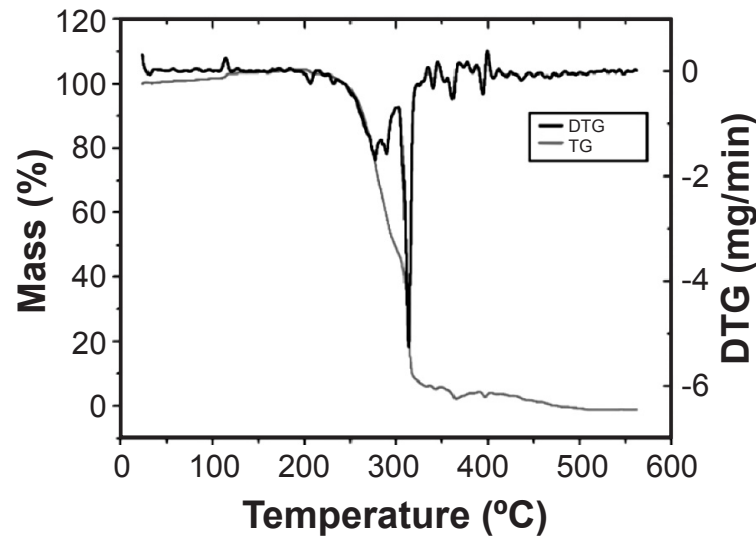

Figure 1: TGA and DTG curves for polyurethane foam.

[Figura 1: Curvas de TG e DTG para a espuma de poliuretano.]

minimum viscosity value. The dispersion of the particles was necessary to avoid the presence of agglomerates and consequently to promote the increase of the solid concentration in the suspension, thus, producing ceramic bodies with higher green densities. The results of the viscosity as a function of the deflocculant concentration of the aqueous K10 montmorillonite clay suspensions are depicted in Fig. 2a. The deflocculant contents found at the minimum viscosity values were $0.012,0.018$, and 0.050 mass $\%$ of sodium polyacrylate for formulations of $48 \%$, $50 \%$, and $52 \%$ concentration of clay, respectively. These minimum viscosity values were at $863.8,1707$, and 2727 $\mathrm{mPa} . \mathrm{s}$, respectively. As expected, the minimum viscosity increased as the solid content of the formulation increased. This was due to the fewer free space available for particle movement. As the concentration of montmorillonite clay particles in suspension increased, the inter-particle friction also increased, which reflected on the rise of the viscosity. This also explained the higher consumption of deflocculant as a consequence of the suspension with a higher concentration of solids (52\%) and, consequently, higher viscosity values when compared to suspensions containing $48 \%$ and $50 \%$ of solids.

The shear stress as a function of the shear rate for the K10 montmorillonite clay aqueous suspensions in concentrations of $48 \%, 50 \%$, and $52 \%$ and deflocculated with $0.012,0.018$, and 0.050 mass $\%$ of sodium polyacrylate, respectively, is shown in Fig. 2b. It was observed that regardless of the concentration of the suspension, the shear stress increased as the shear rate increased. For the formulation with a solid content of $52 \%$, it was observed that the suspension reached a practically constant viscosity from the shear rate of $5 \mathrm{~s}^{-1}$, behaving from that point as a Newtonian flow. However, it was observed that the rheological behavior for all formulations was similar to the rheological behavior of a pseudoplastic flow, in which the viscosity decreases with the increase of the shear rate. This behavior is desirable for the polymeric sponge impregnation process because the viscosity of the ceramic suspension must initially be high, so as not to run from the filaments of the polymeric sponge (hydrophobic) and soon after, it must decrease when passing 

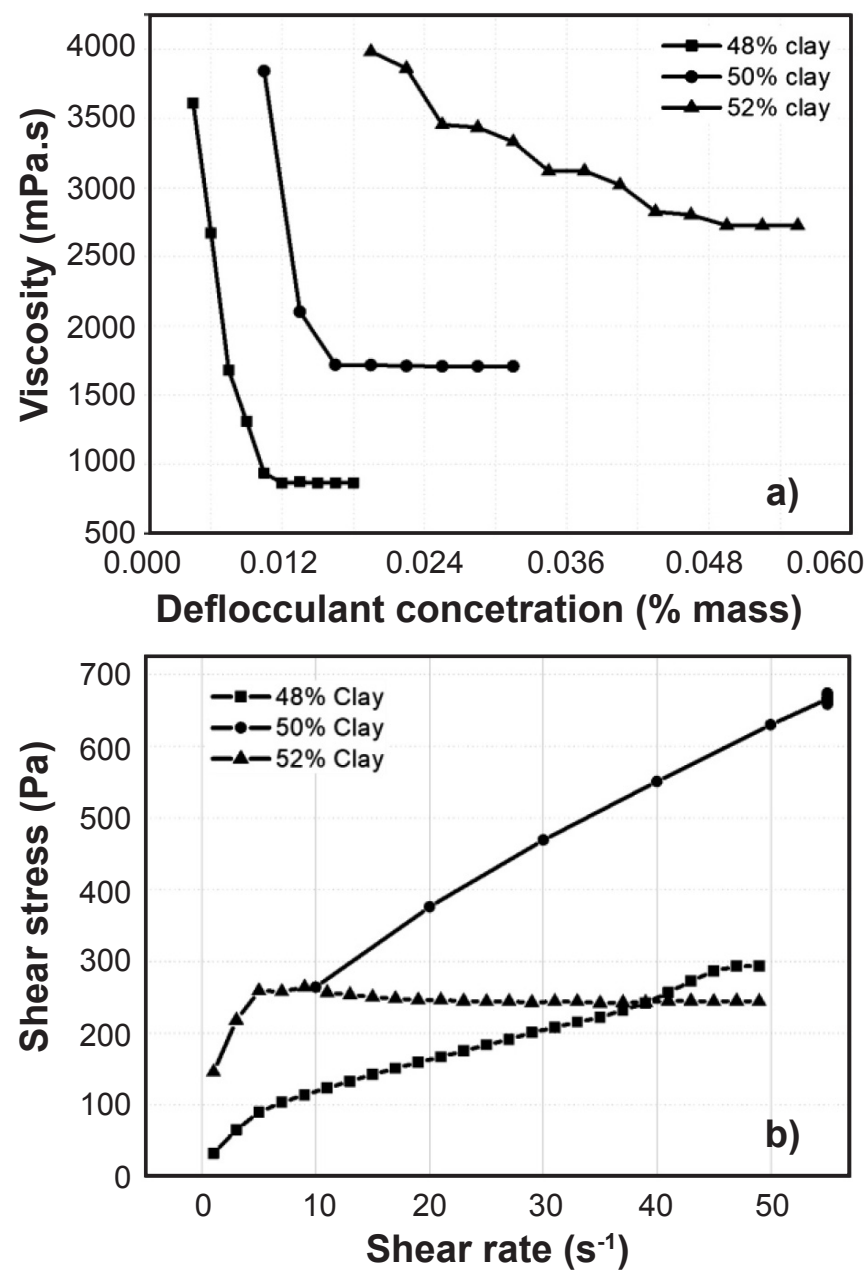

Figure 2: Viscosity curves as a function of deflocculant concentration (a) and plot of shear stress vs. shear rate (b) for suspensions with $48 \%, 50 \%$, and $52 \%$ of K10 montmorillonite clay.

[Figura 2: Curvas de viscosidade em função da concentração de defloculante (a) e gráfico de tensão de cisalhamento vs. taxa de cisalhamento (b) para suspensões com 48\%, 50\% e 52\% de argila montmorilonita K10.]

through the roller (increased shear) to coat all the filaments of the polymeric sponge uniformly. When leaving the roller (null shear), the viscosity should increase again to retain a greater amount of mass on the filaments. The decrease of the suspension viscosity with the increase in the shear rate is due to the degradation of agglomerates or floccules when subjected mainly to high shear rates [31].

Analysis of suspension depositions: the deposition of suspensions on the polyurethane sponges was evaluated (Fig. 3). The results regarding the amount of retained mass in the polymeric sponges that were impregnated by ceramic suspensions of $52 \%, 50 \%$, and $48 \%$ were $82 \%, 76 \%$, and $61 \%$, respectively. It was noted that the suspension containing the highest concentration of solids (52\%) presented the highest content of retained mass in the polymeric sponge, which led to a high degree of cell clogging (Fig. 3a). Whereas, the suspension with the lowest solid concentration (48\%) retained the lowest mass content in the polymeric sponge (Fig. 3c). Thus, there was a decrease in the deposition intensity towards the interior of the sponge. This may affect the mechanical resistance of the ceramic filter due to the low mass content of the ceramic suspension per volume unit. Besides, the suspension with a solid concentration of 50\% showed good structural stability of its cells, better mass impregnation, and less degree of cell clogging (Fig. $3 \mathrm{~b})$. The suspensions with a solid concentration of $48 \%$ and $52 \%$ showed the lowest and highest viscosity after their total deflocculation, respectively (Fig. 2a). Fig. 2b shows that the formulations presented a pseudoplastic behavior, regardless of the solid concentration. Moreover, Fig. 3 shows that suspensions with a solid concentration of $48 \%$ and $52 \%$ resulted in little mass impregnation and high clogging of the macropores, respectively. Based on the rheological analysis data and the deposition of suspensions, the composition of $50 \%$ in mass of K10 montmorillonite clay was chosen as the suspension for the synthesis of ceramic filters. This concentration produced samples with a viscosity suitable to retain a quantity of ceramic mass associated with good mechanical resistance and the lowest degree of poreclogging.

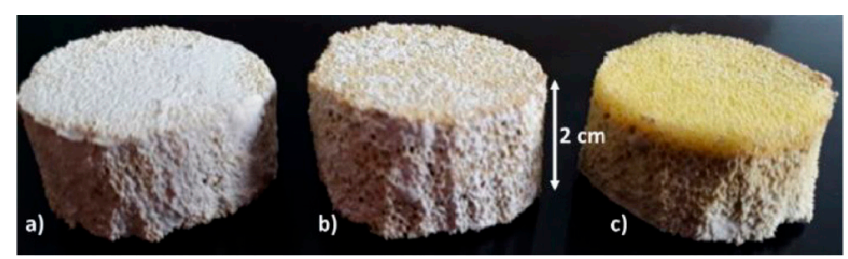

Figure 3: Images of polyurethane sponges after impregnations with K10 montmorillonite clay suspensions with solid contents of: a) $52 \%$; b) $50 \%$; and c) $48 \%$.

[Figura 3: Imagens das esponjas de poliuretano após impregnações com suspensões de argila montmorilonita K10 com teores de sólidos de: a) $52 \%$; b) $50 \%$; e c) $48 \%$.]

XRD analysis: X-ray diffraction patterns of the powders obtained by the Pechini method and calcined at $600{ }^{\circ} \mathrm{C}$ are displayed in Fig. 4a. Similar diffraction patterns were observed for both compositions. The only difference was observed in relation to peak intensities, which was slightly higher for nickel oxide doped with $0.50 \% \mathrm{Ag}$. The diffraction peaks characteristic of rhombohedral $\mathrm{NiO}$ phase were found at $2 \theta=37.24^{\circ}, 43.28^{\circ}, 62.92^{\circ}, 75.40^{\circ}$, and $79.37^{\circ}$ corresponding to the crystalline planes (021), (202), (024), (223), and (042), respectively, according to the PDF 01089-3080. The cubic silver phase was found with peaks at $2 \theta=38.11^{\circ}, 44.27^{\circ}, 64.42^{\circ}, 77.47^{\circ}$, and $81.53^{\circ}$, which were attributed to the crystallographic planes (111), (200), (220), (311), and (222) (PDF 00-004-0783). The XRD patterns of the obtained particles after calcination at 600 and $700{ }^{\circ} \mathrm{C}$ of $\mathrm{NiO}$ and $0.50 \% \mathrm{Ag}$-doped powder samples are shown in Fig. $4 \mathrm{~b}$. It was observed that with the increase in the calcination temperature, there was an increase in the intensity of the diffraction peaks, suggesting an increase in the crystallinity at $700{ }^{\circ} \mathrm{C}$.

Particle size: Table I shows the average particle size (APS) for the powders processed at 600 and $700{ }^{\circ} \mathrm{C}$. It was 
observed that the nickel oxide treated at $600{ }^{\circ} \mathrm{C}$ presented APS of $4.25 \mu \mathrm{m}$; when doped with $0.25 \mathrm{~mol} \%$ of $\mathrm{Ag}$, it presented APS of $4.85 \mu \mathrm{m}$, while for the resin doped with $0.5 \mathrm{~mol} \%$ of Ag, APS increased to $4.94 \mu \mathrm{m}$. The APS of the nickel oxide powders doped with 0.25 and $0.50 \mathrm{~mol} \%$ of $\mathrm{Ag}$ calcined at $700{ }^{\circ} \mathrm{C}$ showed a larger average size compared to the heat-treatment carried out at $600{ }^{\circ} \mathrm{C}$. For $0.25 \mathrm{~mol} \% \mathrm{Ag}$, APS was $5.51 \mu \mathrm{m}$, and for $0.50 \mathrm{~mol} \%$ Ag APS was $5.85 \mu \mathrm{m}$. The particle size increased with temperature due to supplied
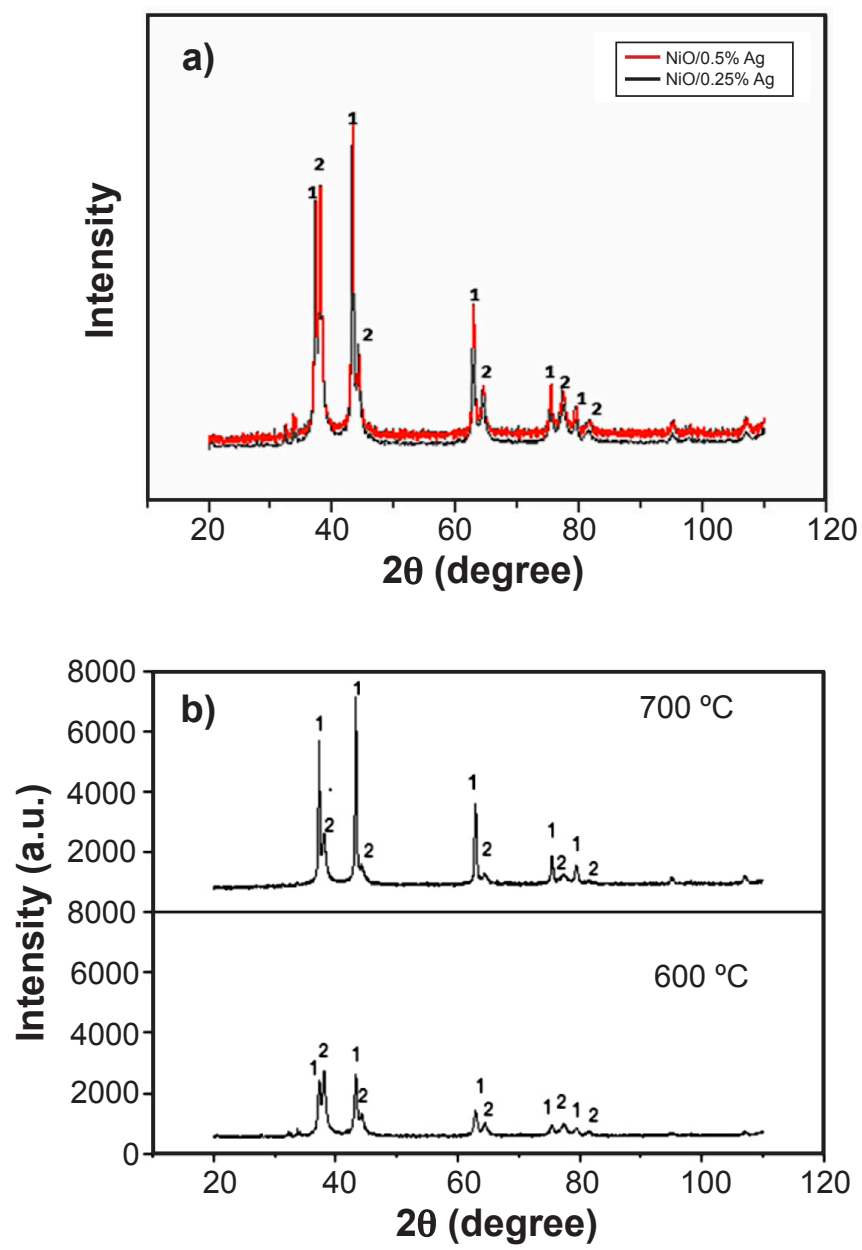

Figure 4: X-ray diffraction patterns of: a) $\mathrm{NiO}$ powders doped with 0.25 and $0.50 \mathrm{~mol} \%$ of $\mathrm{Ag}$ calcined at $600{ }^{\circ} \mathrm{C}$; and b) $0.50 \mathrm{~mol} \%$ Ag-doped $\mathrm{NiO}$ powders calcined at 600 and $700{ }^{\circ} \mathrm{C}$. 1: NiO; 2: Ag. [Figura 4: Difratogramas de raios X de: a) pós de NiO dopados com 0,25 e 0,50\% mol de Ag calcinados a $600{ }^{\circ} \mathrm{C}$; e b) pós de NiO dopados com 0,50\%mol de Ag calcinados a 600 e $700{ }^{\circ} \mathrm{C}$. 1: $\mathrm{NiO}$; 2: Ag.]

Table I - Average particle size $(\mu \mathrm{m})$ for powders calcined at 600 and $700{ }^{\circ} \mathrm{C}$.

[Tabela I - Tamanhos médios de partículas ( $\mu \mathrm{m})$ para os pós calcinados em 600 e $700{ }^{\circ} \mathrm{C}$.]

\begin{tabular}{ccc}
\hline Composition & $600{ }^{\circ} \mathrm{C}$ & $700{ }^{\circ} \mathrm{C}$ \\
\hline $\mathrm{NiO}$ & 4.25 & 4.84 \\
$\mathrm{NiO} / 0.25 \% \mathrm{Ag}$ & 4.85 & 5.51 \\
$\mathrm{NiO} / 0.50 \% \mathrm{Ag}$ & 4.94 & 5.85 \\
\hline
\end{tabular}

energy (heat) that favored the enlargement of the particles because of the coalescence process effect, where smaller crystals were eliminated in the diffusive process.

\section{Characterization of ceramic filters}

Scanning electron microscopy (SEM) and energy dispersive spectroscopy (EDS) of ceramic filters: the micrograph of the inner part of the filter element without the impregnation of silver-doped nickel oxide analyzed by EDS is shown in Fig. 5. It can be seen in the micrograph (Fig. 5a) that the structure was typical of a porous ceramic made by the replica method, presenting filaments and solid parts with pores. Fig. $5 \mathrm{~b}$ shows the presence of the main elements in the sample, associated with the clay mineral montmorillonite $\mathrm{K} 10$, such as $\mathrm{C}, \mathrm{Mg}, \mathrm{Na}, \mathrm{Al}, \mathrm{Si}, \mathrm{K}$, and $\mathrm{O}$, which are in accordance with the results obtained in [32]. The micrograph and EDS of the internal part of the filter element impregnated with nickel oxide doped with $0.25 \mathrm{~mol} \%$ of silver is shown in Fig. 6. The results of EDS microanalysis (Fig. 6b) proved the incorporation of the nickel and silver elements in the filter element.

SEM images of the surfaces of filter samples without and with impregnation of nickel oxide resin doped with 0.50 mol\% silver are shown in Figs. $7 \mathrm{a}$ and $7 \mathrm{~b}$, respectively. It was possible to notice a considerable change on the surface of the filter containing the resin. It was observed that the structure of the filter impregnated with $\mathrm{NiO}$ and doped with $0.5 \mathrm{~mol} \%$ of Ag (Fig. 7b) presented a more cohesive and denser structure than that of the filter without impregnation. Additionally, considering the macropore characteristics, it seems that the normal macroporosity of the polymeric sponge decreased due to the addition of $\mathrm{NiO} / 0.5 \% \mathrm{Ag}\left(700{ }^{\circ} \mathrm{C}\right)$. This result corroborated the data presented in Table II, where the apparent porosity decreased from $58.5 \%$ in the filter without impregnation to $50.4 \%$ in filter with $\mathrm{NiO} / 0.5 \% \mathrm{Ag}\left(700{ }^{\circ} \mathrm{C}\right)$.

Apparent porosity (AP), water absorption (WA), and bulk density ( $B D)$ : Table II shows the results of AP, WA, and $\mathrm{BD}$ of the ceramic filters, determined according to NBR 13818/97 standard [29]. The AP of the filters varied between $50.4 \%$ and $58.5 \%$, WA between $49.9 \%$ and $70.0 \%$, and BD between 1.90 and $2.03 \mathrm{~g} . \mathrm{cm}^{-3}$. The samples impregnated with the silver and nickel oxide resin with the compositions of 0.25 and $0.50 \mathrm{~mol} \% \mathrm{Ag}$ presented similar apparent porosity (AP) values, which did not significantly change with the increase of the calcination temperature. However, the apparent porosity of ceramic filters without impregnation showed a higher value $(58.5 \%)$ due to the presence of a greater number of pores inside the specimens, that is, greater volume in relation to the mass, which was not filled by the resin. Likewise, the ceramic filter without impregnation showed greater water absorption (70.0\%) when compared to the filters impregnated with the resin $(55.1 \%)$. This was due to the presence of a higher number of open pores. The bulk density (BD) of the five samples presented values close to each other. 
a)

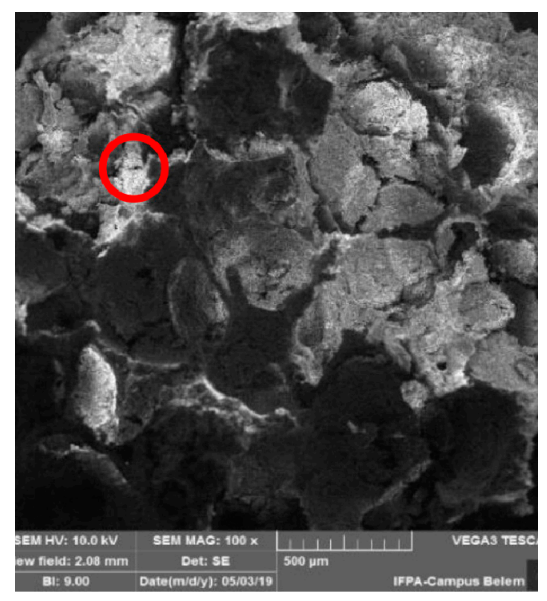

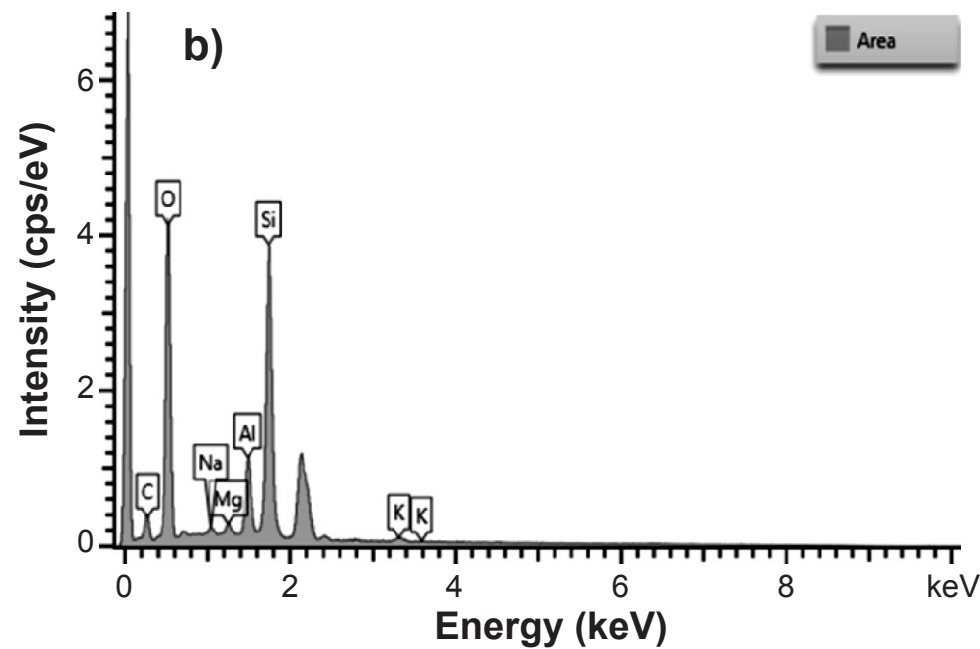

Figure 5: SEM micrograph of the non-soaked filter element (a) and EDS spectrum (b) of the region indicated with a circumference in (a). [Figura 5: Micrografia de MEV do elemento filtrante sem impregnação (a) e espectro de EDS (b) da região indicada com círculo em (a).]

a)

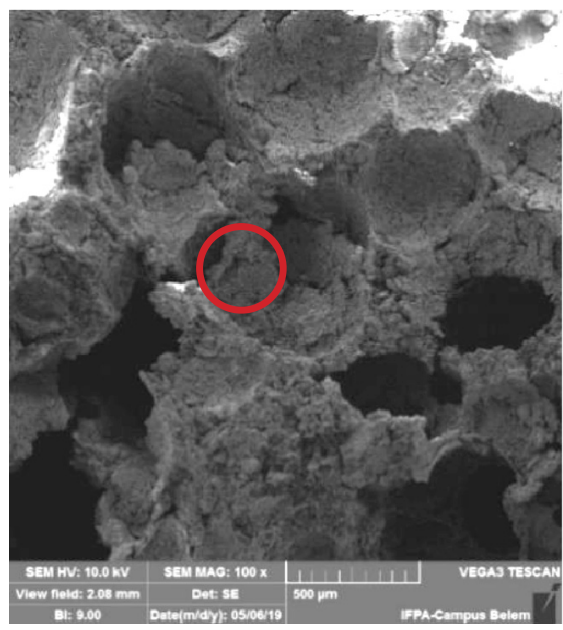

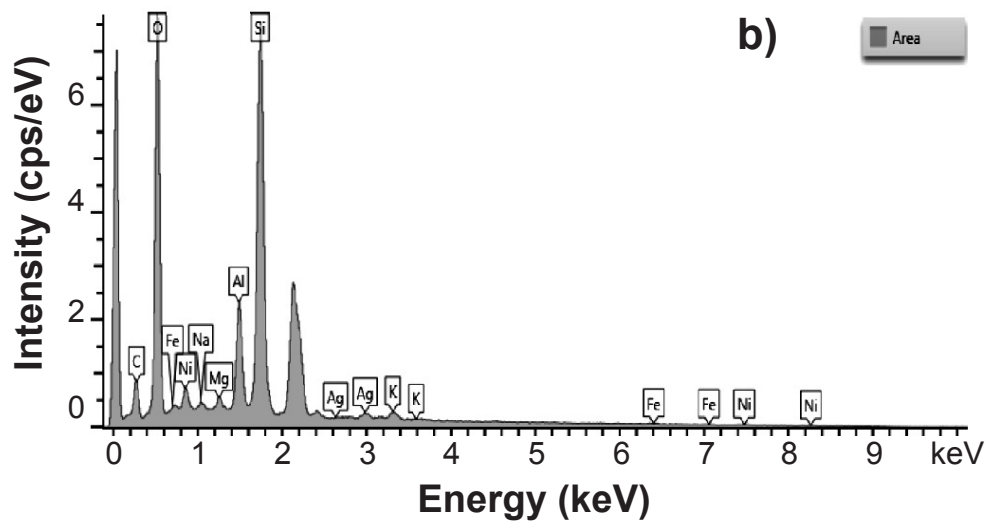

Figure 6: SEM micrograph of $\mathrm{NiO} / 0.25 \mathrm{~mol} \% \mathrm{Ag}$ impregnated filter element (a) and EDS spectrum of filter element impregnated with nickel oxide resin doped with $0.50 \mathrm{~mol} \% \mathrm{Ag}$ at $700{ }^{\circ} \mathrm{C}(\mathrm{b})$.

[Figura 6: Micrografia de MEV do elemento filtrante impregnado com NiO/O,25\% $\%$ mol Ag (a) e espectro de EDS do elemento filtrante impregnado com resina de óxido de níquel dopado com 0,50\% mol $\mathrm{Ag}$ a $\left.700{ }^{\circ} \mathrm{C}.\right]$
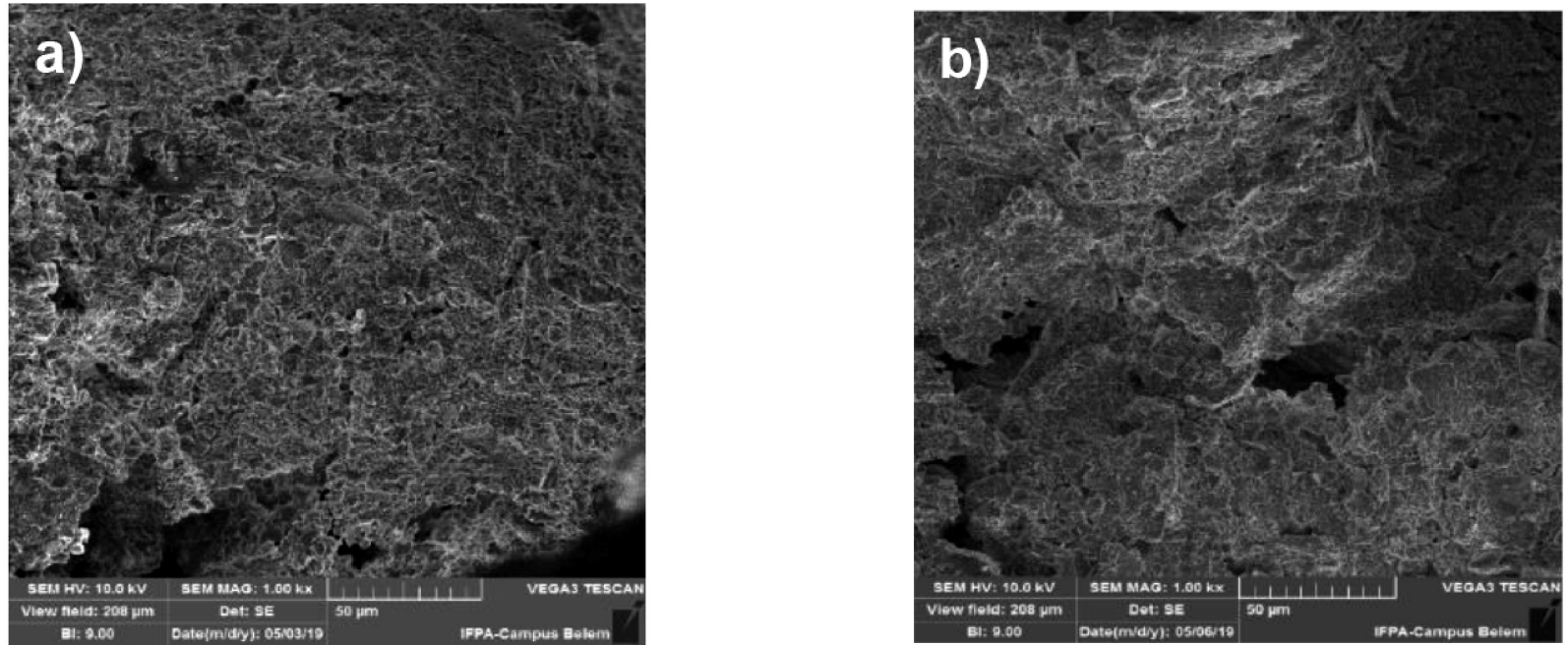

Figure 7: SEM micrographs of filter elements calcined at $700{ }^{\circ} \mathrm{C} / 2 \mathrm{~h}$ : a) without impregnation; and b) impregnated with NiO/0.50 mol $\% \mathrm{Ag}$. [Figura 7: Micrografias de MEV dos elementos filtrantes calcinados a $700{ }^{\circ} \mathrm{C} / 2 \mathrm{~h}:$ a) sem impregnação; e b) impregnado com NiO/0,5\% mol Ag.] 
Table II - Results of the physical characterization of ceramic filters.

[Tabela II - Resultados de caracterização física dos filtros cerâmicos.]

\begin{tabular}{cccc}
\hline Sample & AP $(\%)$ & WA $(\%)$ & BD $\left(\mathrm{g} . \mathrm{cm}^{-3}\right)$ \\
\hline Filter without impregnation & $58.5 \pm 0.4$ & $70.0 \pm 0.6$ & $2.01 \pm 0.05$ \\
Filter with resin $\mathrm{NiO} / 0.50 \% \mathrm{Ag}\left(600{ }^{\circ} \mathrm{C}\right)$ & $50.4 \pm 0.5$ & $49.9 \pm 0.4$ & $2.03 \pm 0.03$ \\
Filter with resin $\mathrm{NiO} / 0.50 \% \mathrm{Ag}\left(700^{\circ} \mathrm{C}\right)$ & $50.4 \pm 1.7$ & $51.8 \pm 0.4$ & $1.96 \pm 0.11$ \\
Filter with resin $\mathrm{NiO} / 0.25 \% \mathrm{Ag}\left(600^{\circ} \mathrm{C}\right)$ & $51.0 \pm 1.8$ & $55.1 \pm 0.4$ & $1.90 \pm 0.14$ \\
Filter with resin $\mathrm{NiO} / 0.25 \% \mathrm{Ag}\left(700^{\circ} \mathrm{C}\right)$ & $51.1 \pm 0.4$ & $51.3 \pm 1.2$ & $2.03 \pm 0.04$ \\
\hline
\end{tabular}

AP: apparent porosity; WA: water absorption; BD: bulk density.

Mechanical resistance: the ceramic sponges manufactured by the replica method produced hollow filaments, resulting in porous walls, which reduced the fracture strength of the solid material to values below the fracture strength of the dense material [33]. Fig. 8 shows the typical force-strain curves of the compression test for the ceramic filters used in this study. The filters submitted to the test were analyzed under the following conditions: filters without resin impregnation and filters impregnated with nickel oxide resin doped with $0.5 \mathrm{~mol} \% \mathrm{Ag}$ treated at 600 and $700{ }^{\circ} \mathrm{C}$. The relationship between strength and porosity has been the subject of studies by several researchers; one of the studies that correlate the strength of cellular structures and porosity is from Gibson and Ashby [33]. Their investigation was based on the solid beam model, assuming the unit cell of the cellular structure is a simple cubic. Here, it was considered other structural parameters, such as length and edge thickness, which are related to the relative density of the cellular material, moment of inertia, and the applied force. Similar to Gibson and Ashby's model [33], Fig. 8 reveals 3 main stages of the force-strain curve under compression for cellular structure: I) in the linear elastic regime, it was observed that the filter sample with no

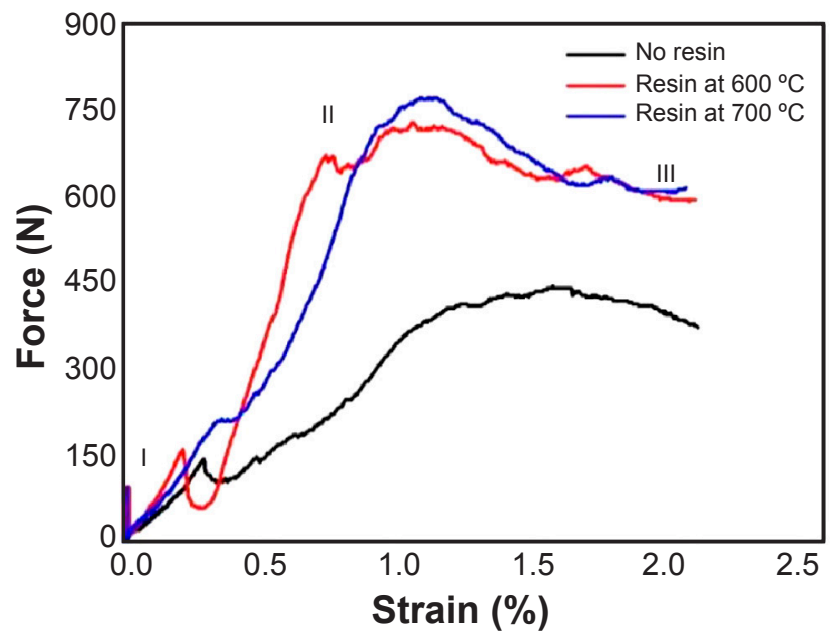

Figure 8: Compressive force-strain curves of non-impregnated and impregnated ceramic filters with $\mathrm{NiO} / 0.50 \mathrm{~mol} \% \mathrm{Ag}$ resin at 600 and $700{ }^{\circ} \mathrm{C}$.

[Figura 8: Curvas de força de compressão-deformação dos filtros cerâmicos sem impregnação e impregnados com resina de $\mathrm{NiO} / 0,5 \% \mathrm{~mol}$ Ag a 600 e $\left.700{ }^{\circ} \mathrm{C}.\right]$

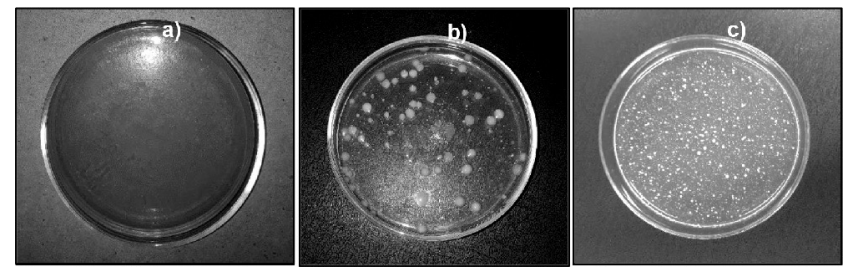

Figure 9: Images of Petri plates showing: a) absence of CFU from S. aureus bacteria for $\mathrm{NiO} / 0.50 \mathrm{~mol} \% \mathrm{Ag}$ impregnated ceramic filter sample at $700{ }^{\circ} \mathrm{C}$; b) presence of CFUs from S. aureus bacteria in $\mathrm{NiO} / 0.25 \mathrm{~mol} \% \mathrm{Ag}$ impregnated ceramic filter sample at $700{ }^{\circ} \mathrm{C}$; and c) presence of CFUs from S. aureus bacteria in a ceramic filter sample not impregnated with resin.

[Figura 9: Imagens de placas de Petri apresentando: a) ausência de unidades formadoras de colônias (UFC) de bactérias $S$. aureus da amostra de filtro cerâmico impregnado com NiO/0,50 \% mol de Ag a $700{ }^{\circ} \mathrm{C}$; b) presença de UFC de bactérias $S$. Aureus na amostra de filtro cerâmico impregnado com $\mathrm{NiO} / 0,25 \%$ mol de $\mathrm{Ag}$ a $700{ }^{\circ} \mathrm{C}$; e c) presença de UFC de bactérias $S$. Aureus na amostra do filtro cerâmico sem impregnação de resina.]

resin presented a maximum load of $130 \mathrm{~N}$; ceramic filters with nickel oxide resin doped with $0.5 \mathrm{~mol} \% \mathrm{Ag}$ at $600{ }^{\circ} \mathrm{C}$ and $0.5 \% \mathrm{~mol} \mathrm{Ag}$ at $700{ }^{\circ} \mathrm{C}$ reached a maximum load of 155 and $215 \mathrm{~N}$, respectively; II) stress level, corresponding to the progressive fracture of the fibers, especially observed in filters impregnated with nickel oxide resin doped with 0.5 mol\% Ag; and III) densification, where the cells collapsed, and subsequent loading pushed the edges and faces of the cells against each other. Specifically, in stage II (Fig. 8), it was observed that the filters impregnated with nickel oxide resin doped with $0.5 \mathrm{~mol} \% \mathrm{Ag}$ at 600 and $700{ }^{\circ} \mathrm{C}$ showed practically no significant differences between the maximum load values. This result was corroborated by the apparent porosity, which values had no differences between these samples (Table II). However, the filter without impregnation showed the lowest maximum load value, which was correlated with its higher apparent porosity (Table II).

Bacteriological analysis: it was verified that the filter impregnated with the resin of composition of 0.50 mol\% of silver presented efficient results for the bacteria Staphylococcus aureus (Fig. 9a) and Escherichia coli. This was because it eliminated these bacteria when the sample was submitted to colony-forming unit (CFU) analysis, with no colonies on the plates, thus preventing the growth and formation of colonies. As observed in the bactericidal test, 
for both the filtration plate from the filter without resin (Fig. 9c) and the filtration plate from the filter doped with nickel oxide in the composition of $0.25 \mathrm{~mol} \% \mathrm{Ag}$ (Fig. 9b), it was not possible to count the number of colonies of S. Aureus and E. Coli bacteria, as they had an overpopulation of CFU. The fact that the higher concentration is more efficient is linked to the particle size and its distribution in the ceramic filter. This happens due to the great adhesion of silver ions on the surface and inside the ceramic filters, as well as some aspects of silver, such as its crystallinity, geometry, dimensions, and surface area, although the variation of its dimension and surface influence the bactericidal effect differently. This metal, in small concentrations, is highly lethal to bacteria. Additionally, depending on the concentration value of $\mathrm{Ag}$, the inhibition or destruction of the living organism may occur [34].

\section{CONCLUSIONS}

Ceramic filters with bactericidal action for water disinfection was produced and examined in detail. The results obtained led to the following conclusions: i) the sponges impregnated with the suspension with 50\% clay showed the best dispersion of the particles, obtaining ceramic bodies with well-defined structures; ii) the characterization of the resins by X-ray diffraction revealed characteristic peaks of rhombohedral nickel oxide phase and cubic silver phase, which agreed with the crystallographic patterns found in the literature; iii) from SEM analysis, it was verified the presence of an open cell structure in the filters that corresponded to the structure of polyurethane precursor; through the qualitative chemical analysis of the filters impregnated with the resin, it was possible to observe the constituent elements of the clay and the presence of the nickel and silver; iv) in bactericidal tests, the surface of filter impregnated with nickel oxide doped with $0.5 \mathrm{~mol} \%$ silver revealed high potential application for the disinfection of water contaminated with E. coli and S. aureus, promoting total elimination of these microorganisms; and $\mathrm{v}$ ) this product has a great potential to be applied for water treatment and requires low-cost process and limited quantities of reagents to the impregnation process.

\section{ACKNOWLEDGMENTS}

The authors thank the financial support of the Brazilian research funding institutions FAPEMA (Process: UNIVERSAL-00768/17), CAPES, the Postgraduate Program in Materials Engineering-PPGEM, IFPA for the analysis of SEM and the Federal Institute of Education, Science and Technology of Maranhão-IFMA for its support in the development of this work.

\section{REFERENCES}

[1] R. Bain, S. Gundry, J. Wright, H. Yang, S. Pedley, J. Bartram, Bull. World Health Organ. 90, 3 (2012) 228.
[2] Q. Li, S. Mahendra, D.Y. Lyon, L. Brunet, M.V. Liga, D. Li, P.J. Alvarez, Water Res. 42, 18 (2008) 4591.

[3] N.H. Mthombeni, L. Mpenyana-Monyatsi, M.S. Onyango, M.N.B. Momba, J. Hazard. Mater. 217-218 (2012) 133.

[4] S.A. Jassim, R.Z. Al Zubaidy, H.R. Habib, Baghdad Sci. J. 11, 2 (2014) 730.

[5] E.A. Zereffa, T.B. Bekalo, Mater. Sci. Appl. Chem. 34 (2017) 69.

[6] S.I. Akosile, F.O. Ajibade, K.H. Lasisi, T.F. Ajibade, J.R. Adewumi, J.O. Babatola, A.M. Oguntuase, Sci. African 7 (2020) e00218.

[7] G.V.E. Cabala, W. Acchar, Mater. Today Proc. 2, 1 (2015) 321 .

[8] V.R. Salvini, B. Luchini, C.G. Aneziris, V.C. Pandolfelli, Int. J. Appl. Ceram. Technol. 16, 1 (2019) 378.

[9] A. Rincóna, G. Giacomello, M. Pasetto, E. Bernardo, J. Eur. Ceram. Soc. 37 (2017) 2227.

[10] R.P.S. Dutra, L.R. de Araújo Pontes, Cerâmica 48, 308 (2002) 223.

[11] I.J.Kim, J.G. Park, Y.H. Han, S.Y.Kim, J.F. Shackelford, J. Kor. Ceram. Soc. 56, 3 (2019) 211.

[12] W. Acchar, F.B.M. Souza, E.G. Ramalho, W.L. Torquato, Mat. Sci. Eng. A 513-514 (2009) 340.

[13] K.Z. Huanca, A.B. de A. Nunes, Cerâmica 62, 362 (2016) 110.

[14] A.C. Chaves, H.L. Lira, G.A. Neves, F.A. Silva, R.C.O. Lima, K.B. França, Cerâmica 59, 349 (2013) 192.

[15] A.R.V. Silva, H.C. Ferreira, Rev. Eletr. Mater. Proc. 3, 2 (2008) 26.

[16] A.B. Luz, F.A.F. Lins, Rochas \& minerais industriais: usos e especificações, $2^{\text {nd }}$ ed., CETEM/MCT, Rio Janeiro (2008).

[17] A.C.V. Coelho, P.S. Santos, H.S. Santos, Quim. Nova 30, 1 (2007) 146.

[18] H.T.S. Braibante, M.E.F. Braibante, Ciên. Nat. 36, ed. esp. II (2014) 724.

[19] S.O. Obaje, J.I. Omada, U.A. Dambatta, Int. J. Sci. Tech. 3, 5 (2013) 264.

[20] E. Teixeira-Neto, A.A. Teixeira-Neto, Quim. Nova 32, 3 (2009) 809.

[21] J.-Q. Jiang, Z. Zeng, P. Pearce, Water Air Soil Pollut. 158 (2004) 53.

[22] P. Dallas, V.K. Sharma, R. Zboril, Adv. Colloid. Interface Sci. 166 (2011) 119.

[23] J.R. Morones, J.L. Elechiguerra, A. Camacho, K. Holt, J.B. Kouri, J.T. Ramirez, M.J. Yacaman, Nanotechnology 16 (2005) 2346.

[24] K.N. Jackson, J.A. Smith, J. Nanotechnol. 2018 (2018) 2573015.

[25] K.N. Jackson, J.A. Smith, J.N. Edokpayi, Environ. Eng. Sci. 36, 1 (2018) 2.

[26] M. Morales, R.B. Merlo, R. Droppa Jr, F. Alvare, J. Phys. D Appl. Phys. 47 (2014) 195303.

[27] M.D.M. Innocentini, S. Pilar, V.R. Salvini, V.C. Pandolfelli, J.R.J. Coury, J. Amer. Ceram. Soc. 81, 12 (2005) 3349. 
[28] M. Pechini, "Method of preparing lead and alkalineearth titanates and niobates and coating method using the same to form a capacitor", U.S. Patent 3330697 (1967).

[29] ABNT NBR 13818, "Placas cerâmicas para revestimento: especificação e métodos de ensaios” (1997).

[30] C.B. Silveira, J.A. Escobar, M.W. Quintero, Quim. Nova 30, 5 (2007) 1104.

[31] A.E.M. Paiva, M.C. Lario, V.C. Pandolfelli, J.A. de Rodrigues, Cerâmica 42, 276 (1996) 395.
[32] K. Kalantari, M. B. Ahmad, K. Shameli, M.Z.B. Hussein, R. Khandanlou, H. Khanehzaei, J. Nanotechnol. 2014 (2014) 739485.

[33] L.J. Gibson, M.F. Ashby, Cellular solids-structure and properties, $2^{\text {nd }}$ ed., Cambridge Un. Press (1997).

[34] E.N.L. Rodrigues, E.J.P. Miranda, M.M. Oliveira, Mater. Sci. Forum 798-799 (2014) 69.

(Rec. 10/03/2020, Rev. 02/06/2020, 16/06/2020, Ac. 22/06/2020) 